months in assisting university teachers and investigators who, on grounds of race, religion or political opinion, are unable to carry on their work in their own countries. The Council has collected records of about one thousand displaced scientific workers and scholars. One hundred and thirty-two have been given temporary research facilities in the Universities and University Colleges of Belfast, Birmingham, Bristol, Cambridge, Cardiff, Edinburgh, Glasgow, Hull, Leeds, London, Manchester, Nottingham and Oxford. In forty-two instances the Council has made maintenance grants for one year; such grants are limited to $£ 250$ a year for a married and $£ 182$ for an unmarried person. Donations received by the Council up to November 4 amounted to $£ 9,69514 \mathrm{~s}$.;

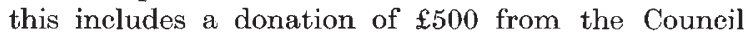
of Trinity College, Cambridge. Unless a further substantial sum is available the Council can make no more grants. The Council is making inquiries throughout the world to discover permanent or semi-permanent openings for displaced academic workers, and every care is being taken not to prejudice the interests of university teachers or others intending to follow an academic career. The Council intends to appeal immediately for further funds, but to avoid a multiplication of public appeals of a similar character it has decided to issue its own in co-operation with the International Student Service, the Refugee Professionals Committee and the Germany Emergency Committee of the Society of Friends. Contributions-earmarked if desired for the Academic Assistance Council-may be sent to Mr. Walter Adams, the General Secretary of the German Refugees Assistance Fund (Academic and Professional) at 232, Abbey House, Westminster, S.W.1. (Telephone: Victoria 5927.)

\section{Permanent Documents}

THE preservation of documents, pictures and other records of historical importance is a problem of grave importance to librarians and others. The Royal Photographic Society in 1927 appointed a committee to recommend methods for the preservation of photographic records (Phot. $J, 67,498-499$; 1927). The report of this committee contained a very useful set of recommendations. It directed attention, however, to the fact that photography itself is so young that little can be said as to the ultimate 'staying power' of photographic records. The problem of permanence usually involves two main factors; the behaviour of the base and that of the characters or designs recorded upon it. The common bases used in photography vary greatly in stability, as may be judged by mentioning a few ; glass, paper, celluloid. On the other hand, different types of photographic image show just as great variety. Other records, not photographic, present similar variations.

USUALLY the methods yielding records of outstanding resistance to chemical ageing, such as tilemaking, etc., are troublesome, if only for the great bulk of the product. An invention by Mr. Everard Digby, 6 Queen Anne's Gate, London, S.W.1, appears to have opened a new field for those who anticipate preserving records for all time. The process is based on photography and lends itself to the reproduction of any designs in line or half-tone, as well as to the reproduction of printed or other characters. All the advantages of accuracy are thus obtained. The novelty in the process consists in the use of gold and platinum as the working materials. In the examples which Mr. Digby has already shown, the main substratum is made from sheets of 14-18 carat gold $0.004 \mathrm{in}$. in thickness. Upon these are placed, in perfect contact, thin films of polished platinum. The characters or designs are then formed as matte areas on the polished platinum. The inventor claims that such metallic sheets will be immune from almost every possibility of chemical disfigurement. In addition they would not be so much exposed to the danger of being thrown away as being of no value.

\section{Conference of Australian Physicists and Astronomers}

THE fourth conference of Australian physicists and astronomers, arranged by local members of the Institute of Physics, was held in Melbourne on August 15-18, and was attended by fifty delegates from various parts of the Commonwealth. In his presidential address on "The Place and Value of Physical Science in the Modern State", Prof. Kerr Grant stressed the value of the study of pure science as a training for orderly and objective thinking. He showed that every advance in applied science is based on discoveries made in pure science, and urged the cultivation of scientific investigation for its own sake. An address on "Contemporary Physics" was given by Dr. H. S. W. Massey and a discussion took place on the organisation of the observatories in Australia (see NATuRE of April 23, 1932), a question which had been referred to the conference by the Commonwealth Government. A description of the results obtained in the investigation of the effects of fading and of atmospherics in the reception of broadcast signals was given by the staff of the Radio Research Board. Because of the high incidence of thunderstorms in Australia, atmospheric interference is an important problem in broadcasting, and the results obtained with two cathode ray direction-finding stations and a narrow sector continuous recorder over a period of more than two years are yielding information of considerable value. A number of papers were also read describing research work in progress on the motions of electrons in gases, on the thermal conductivities of gases, on long wave-length $\mathrm{X}$-rays, and on the oscillations produced by a valve oscillator. The radon purification plant in use in the Commonwealth Radium Laboratory; and that proposed for use in Perth, were described and discussed.

\section{Progeny Records at Live-Stock Sales}

IT can be safely stated that the majority of the great 'improvers' of our breeds of live-stock were familiar with the criterion of judging the value of a sire by his progeny. In recent years, particularly as regards the breeders of dairy cattle, there has 